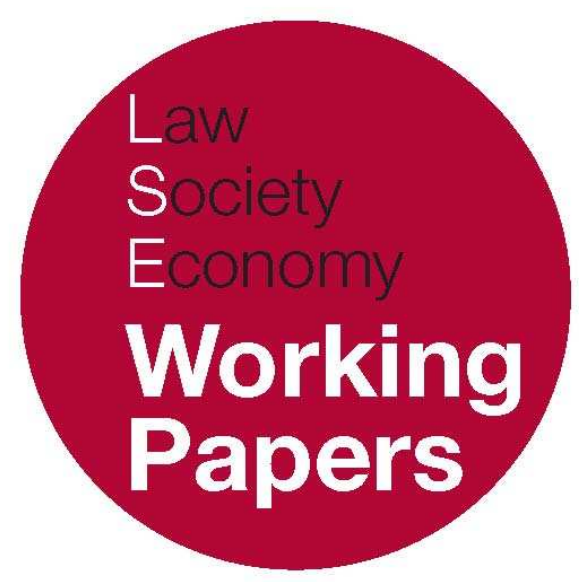

\title{
Prior Notification in Privacy Cases: A Reply to Professor Phillipson
}

\author{
Andrew Scott \\ LSE Law, Society and Economy Working Papers 09/2010 \\ London School of Economics and Political Science \\ Law Department
}

This paper can be downloaded without charge from LSE Law, Society and Economy Working Papers at: www.lse.ac.uk/collections/law/wps/wps.htm and the Social Sciences Research Network electronic library at: http://ssrn.com/abstract=1610273.

A revised version of this paper, taking into account the comments and suggestions of the journal editors and referee, is forthcoming in (2010) 2(1) Journal of Media Law 49 at www.hartjournals.co.uk/jml <outbind://4/www.hartjournals.co.uk/jml>.

(C) Andrew Scott. Users may download and/or print one copy to facilitate their private study or for non-commercial research. Users may not engage in further distribution of this material or use it for any profit-making activities or any other form of commercial gain. 


\title{
Prior Notification in Privacy Cases: A Reply to Professor Phillipson
}

\author{
Andrew Scott ${ }^{*}$
}

\begin{abstract}
In a recent edition of the Journal of Media Law, Professor Gavin Phillipson considered whether the United Kingdom must impose a prior notification obligation on the media in respect of stories that concern the private conduct of individuals. Such a notification requirement would allow time for the subjects of such stories to seek interim relief to prevent publication. Max Mosley has asked the European Court of Human Rights to oblige the UK to introduce such a rule. Professor Phillipson concluded that Mosley should win his case. This paper proceeds, first, by questioning the fundamental premise of the Phillipson / Mosley argument: that damages are inadequate to compensate harms done through publication of private information. Secondly, it considers the practical ramifications of the imposition of a prior notification requirement, both in terms of the 'workability' of a legal obligation and the impact it would have on media freedom. Thirdly, it airs the question of whether - in light of the margin of appreciation afforded to contracting states - it would be legitimate for the Strasbourg court to compel the introduction of a specific measure to assist the protection of privacy. The paper concludes that the European Court should not find the United Kingdom in breach of its obligations. Nevertheless, it closes with reflections on the desirability of prior notification, and the availability of other means to encourage the practice.
\end{abstract}

\footnotetext{
* Law Department, London School of Economics and Political Science. The author would like to thank Gavin Phillipson for the helpful discussions entered in the preparation of this paper. He has been the model of the open and self-critical scholar. I have also had the opportunity to consider the interventions made in Mosley v United Kingdom (App no. 48009/08) by the Media Legal Defence Initiative and others, the Media Lawyers Association, and Guardian News and Media Ltd. These can be accessed on the Inforrm blog at http://inforrm.wordpress.com/2010/04/09/mosley-echr-case-the-media-submissions/ (accessed April 2010).
} 


\section{INTRODUCTION}

In a recent edition of the Journal of Media Law, ${ }_{1}$ Professor Gavin Phillipson addressed the question of whether 'in order to ensure effective protection of Article 8 rights, UK law needs in some way to provide that newspaper editors, before publishing [stories concerning the private details or conduct of individuals], should contact their subject'. ${ }^{2}$ That is, whether the media should be subject to a prior notification requirement in such cases. The argument he offered is closely related to, but developed further than, that presented by Max Mosley to the European Court of Human Rights following his experiences at the hands of the News of the World and in the subsequent legal consideration of his claims. ${ }^{3}$ Professor Phillipson concluded that there is a 'very broad consensus that an interim injunction will usually be the only satisfactory legal means of protecting privacy'. ${ }^{4}$ In light of this, he asserted that the UK must provide a means whereby the protection provided by injunctions is available to claimants as a matter of practical reality. ${ }^{5}$ In undertaking this task, he set out both to justify his own position and to engage with a range of counter-arguments that he expected might be raised against his views. It is a tightly-argued and persuasive article.

That said, Professor Phillipson's key premise and therefore his conclusions are not unimpeachable. Moreover, while he recognises and in some measure engages with contrary views, he does not always fully value their potency and hence does not nullify their practical significance. The aim of this article, then, is to reconsider the validity of the arguments presented in Professor Phillipson's paper, and to reprise the counter-arguments in the hope of salvaging their importance. Ultimately, it is intended to justify the contrary conclusion to that expounded by Professor Phillipson. The imposition of a positive, legal requirement on media organisations to notify in advance the subjects of journalists' stories where these might impinge upon putative Article 8 rights is not required in order that the United Kingdom satisfy its Convention obligations. This is not to argue that such a system may not be desirable. Rather, it is contended that it cannot be mandated by the Strasbourg court by reference to Article 8, and that if it was to be introduced this would be at the discretion of the relevant national authorities. Before introducing any such regime, however, Parliament and/or the courts would have to pay more heed to arguments based upon Article 10. Otherwise, the risk would be that any prior notification requirement could see

1 G. Phillipson, 'Max Mosley Goes to Strasbourg: Article 8, Claimant Notification and Interim Injunctions' (2009) 1 Journal of Media Law 73.

2 ibid, 73.

${ }_{3}^{3}$ Mosley v News Group Newspapers Ltd [2008] EWHC 687 (QB) (application for interim injunction); [2008] EWHC 2341 (QB) (application for strike out of claim for exemplary damages), and [2008] EWHC 1777 (QB) (final judgment). While the Strasbourg case has been expedited, at the time of writing no judgment has yet been handed down. Indeed, it is not yet clear whether there will be an oral hearing.

4 Phillipson, $\mathrm{n} 1$ above, 96.

5 ibid. 
the media become beholden to the courts, and position judges in the editorial seat in a manner ill-suited to a modern democratic polity.

This paper proceeds, first, by questioning the fundamental premise that there is a consensus to the effect that damages are inadequate to compensate harms done through publication of private information. Secondly, the practical ramifications of the imposition of a prior notification requirement, both in terms of the 'workability' of such a system and the impact of such a regime on media freedom, are considered. Thirdly, the question of whether - in light of the earlier points - it would be legitimate for the Strasbourg court to compel the introduction of a specific measure to assist the protection of privacy is aired. As noted above, the paper concludes that the European Court should not find the United Kingdom in breach of its obligations. Nevertheless, it closes with some brief reflections on the desirability of a prior notification requirement. This focuses attention on the constructive suggestions offered by Professor Phillipson - and more recently by the House of Commons Select Committee on Culture, Media and Sport - as to how such might be introduced.

\section{CONTESTING THE PREMISE: IS AN INTERIM INJUNCTION THE ONLY EFFECTIVE REMEDY?}

The fundamental premise of Professor Phillipson's paper is that interim relief is critical in privacy cases; that only such a remedy can secure the effective protection of Article 8 rights. Damages are considered inadequate to compensate the harm done. It is asserted with evidence that there exists an 'overwhelming', 'more or less universal agreement' on this point among academics and jurists, both in the United Kingdom and in other jurisdictions. ${ }^{6}$ Following from the fundamental premise, Professor Phillipson contends that editors must make access to interim relief possible for the claimant by way of prior notification of a pending story. Moreover, he argues that to leave the decision as to whether to notify solely in the hands of an editor entails that the remedy for breach of privacy rights cannot be understood as being 'prescribed by law'. This is thought especially the case, because editors are commercially incentivised, perhaps insensitised, and some at least are contemptuous of both the valuation of privacy in the Convention and of the judges who deploy it in their decisions. Hence, the state must somehow compel prior notification to take place.

On one level the fundamental premise proffered by Professor Phillipson is, and the various professors and judges cited are, obviously correct. No claimant aside, perhaps, from the most venal ${ }^{7}$ - would prefer to seek a remedy for the publication of private information ex post if a preventative option were available. It

\footnotetext{
${ }^{6}$ Phillipson. $\mathrm{n} 1$ above, 75, 81.

7 One has in mind here the apocryphal story of the Member of Parliament who positively invited libellous comment as the only sure-fire way to a free lunch.
} 
is certainly true that 'the outcome of court cases cannot restore privacy in the way that it can restore reputation'. ${ }^{8}$ Everyone can agree that it is best that injury to others is not caused, and that British media organisations - especially the tabloid press - do sometimes wreak tremendous harm to individuals.

Preaching against the sin of injuring others, however, is not the same as demonstrating that a legal remedy in damages provided by the State through the courts cannot be adequate or effective in compensating for privacy harms. On this specific issue, the viewpoints of members of the judiciary here and abroad are more equivocal than Professor Phillipson allows. For example, in the recent case of Terry (originally LNS) v Persons Unknown, Mr Justice Tugendhat considered that 'damages may be an adequate remedy in some cases, if not in all'. ${ }^{9}$ In the case of Hosking $\mathrm{v}$ Runting in the New Zealand Court of Appeal, Gault P noted that in most cases, damages will be considered an adequate remedy'; ${ }^{10}$ Tipping J agreed: 'I see the remedy for invasion of privacy as being primarily an award of damages. ${ }^{11}$ Asked to impose a prior notice obligation in an order imposing reporting restrictions in the context of child care proceedings, Mr Justice Munby considered that this would be 'fundamentally objectionable', 'wrong in principle', and 'a wholly unacceptable attempt at censorship.' ${ }^{\prime 2}$ Considering the matter from the other angle, Lord Scarman famously once declared that 'the prior restraint of publication, though occasionally necessary in serious cases, is a drastic interference with freedom of speech and should only be ordered where there is a substantial risk of grave injustice'. 13

Three further arguments are posited in the paragraphs that follow to contest the premise upon which Professor Phillipson relies. First, it is contended that the consensus he perceives must be lacking given that Parliament has proven itself perfectly comfortable with the idea that damages are - at least in all but the exceptional case - fit to remedy harm to privacy caused by publication. Secondly, and perhaps more controversially, it is suggested that the substantive contention that interim awards are necessary in this context is not solidly founded. Finally, an analogous situation arising from the context of the award of interim injunctions in privacy cases - this time facing media defendants and the limitation of their rights

\footnotetext{
8 Phillipson, $\mathrm{n} 1$ above, 75. Original emphasis.

${ }^{9}$ [2010] EWHC 119 (QB), para 127. In doing so, he echoed Lord Denning MR in Woodward v Hutchins [1977] 1 WLR 760. In both cases, the views expressed owed at least something to the perception that the cases in misuse of private information and confidentiality respectively while tenable had been brought so as to avoid the greater stringency of the test for the award of an interim injunction in libel. 10 [2004] NZCA 34, para 158.

11 ibid, para 258.

12 Kent CC v B (A Child) [2004] EWHC 411 (Fam), para 145.

13 Attorney-General v British Broadcasting Corporation [1981] AC 303, 362. This sentiment was subsequently echoed in the leading Strasbourg case on prior restraint, Observer and Guardian v UK (1992) 14 EHRR 153, para 60: 'the dangers inherent in prior restraints are such that they call for the most careful scrutiny on the part of the court'. See, generally, E. Barendt, Freedom of Speech (Oxford: Oxford University Press, 2nd ed, 2005) ch 4.
} 
to freedom of expression - is sketched, and the absence in that context of any legal obligation to give notice is noted.

\section{ABSENCE OF CONSENSUS ON INADEQUACY OF DAMAGES AS A PRIVACY REMEDY}

The contention that there is a near-consensus on the proposition that damages are an ineffective remedy is somewhat belied by decisions taken by Parliament and the courts over the last ten or fifteen years with regard to the availability of interim injunctions. The threshold test for the award of an interim injunction in civil actions has been redesigned by Parliament in the Human Rights Act 1998 and subsequently interpreted by the courts. The mechanism introduced would seem to imply a degree of comfort with the idea that publication of private information will occur from time to time to be compensated by way of damages only. This point can be made more strongly by reference to the approach adopted by Parliament to journalistic publication of sensitive personal data in the Data Protection Act 1998. This explicitly negates even the possibility that an injunction might be awarded to defend privacy interests in exactly the same circumstances as might found an action for misuse of private information.

\section{Revision of the test for award of interim injunctions}

In section 12 of the Human Rights Act 1998 Parliament attempted to buttress press freedom against the assertion of other incipiently justiciable Convention rights. In its various subsections the provision introduced a general procedural expectation that applications for interim relief will be held inter partes, ${ }^{14}$ a new threshold test for the award of interim orders, ${ }^{15}$ and a number of particular factors that courts were henceforth required to take into account when considering the award of relief in cases involving journalistic material. ${ }^{16}$ It has been contended that the provision has had little impact on the development of law in this area, and that in consequence it 'serves no sensible purpose'. ${ }^{17}$ The generality of this critique may well be fair, but it would seem difficult to contest that - for most cases - the provision has altered the focus of the test as to when an interim injunction should be allowed by the court.

The pre-existing common law rule - which still applies in cases where freedom of expression is not relevant - comprises two stages. The first, gateway

\footnotetext{
${ }^{14} \mathrm{~s}$ 12(2). This rule is subject to two exceptions: first, if the court is satisfied that the applicant has taken all practicable steps to notify the respondent, and secondly, where the court is satisfied that there are compelling reasons why the respondent should not be notified.

15 s $12(3)$.

16 s $12(4)$.

${ }^{17}$ Lester, Pannick, and Herberg, Human Rights Law and Practice (London: LexisNexis, 3rd ed, 2009) para 2.12, n1. Certainly, the impact of this measure has been less than some in the media might have wished as courts have interpreted the provision as imposing no 'presumptive priority' for Article 10 over other rights - see Ashdown v Telegraph Group Ltd [2001] EWCA Civ 1142, para 27 (per Lord Phillips MR); Re S (a child) (identification: restriction on publication) [2003] EWCA Civ 963, para 52 (per Lady Justice Hale), and [2004] UKHL 47, para 17 (per Lord Steyn).
} 
requirement is that there should be 'a serious question to be tried'. ${ }^{18}$ Beyond this, the court focuses on the 'balance of convenience' between the parties. The essence of this approach is the determination of the side on which more would be lost, and the assessment of whether damages granted at the substantive hearing would amount to adequate compensation for an aggrieved party. It is an explicit balancing of the nature of the loss likely to be suffered by the claimant on one hand, against the infringement of the publisher's right to freedom of expression and the wider social value to be gleaned from its exercise on the other. Where the respective parties have equally much to lose, a 'counsel of prudence' encourages the taking of measures 'calculated to preserve the status quo'.19 That is, any equivalence of position is decided in favour of the applicant.

Section 12(3) provides the revised statutory rule for the award of interim injunctions in cases where freedom of expression may be affected. It stipulates that 'no such relief is to be granted so as to restrain publication before trial unless the court is satisfied that the applicant is likely to establish that publication should not be allowed'. As interpreted by Lord Nicholls in Cream Holdings, in the normal case 'likely to establish' is understood as meaning 'more likely than not'. 20 The likelihood of winning at trial is installed as the test for the grant of a prepublication injunction. The burden of proof in the application for interim relief lies squarely on the claimant. In Lord Browne of Madingley $\mathrm{v}$ Associated Newspapers Ltd, Sir Anthony Clarke MR explained that it is 'for the claimant to persuade the judge, in respect of each category of information, that his prospects of success at the trial are sufficiently favourable to justify [...] an order being made in the particular circumstances of the case'. ${ }^{21}$ Any uncertainty on the part of the judge is to be resolved in favour of publication. This was a deliberate change from the preexisting common law rule: 'the exercise which the court is required to perform is $[\ldots]$ altogether different. 22

Thus, the deliberate choice taken by Parliament in this context was to forego the balance of convenience test that saw explicit attention paid to the nature of the harm that would be suffered by the claimant. The legislators accepted that in some cases where publication could in future be proven to have caused privacy harm, it would nonetheless be more important to avoid any restriction on freedom of speech. This circumstance would arise whenever a judge could not be persuaded that the putative privacy right was likely to be vindicated at trial. During the passage of the Bill through Parliament, Jack Straw MP as Home Secretary explained that under the new test:

\footnotetext{
18 American Cyanamid v Ethicon [1975] AC 396, 407 (per Lord Diplock).

$19 \mathrm{ibid}, 408$ (per Lord Diplock).

${ }^{20}$ Cream Holdings Ltd v Banerjee [2004] UKHL 44, para 22.

21 [2007] EWCA Civ 295, para 43.

22 Cream Holdings Ltd v Banerjee [2003] EWCA Civ 103, para 103 (per Lady Justice Arden).
} 
the courts should consider the merits of an application when it is made and should not grant an interim injunction simply to preserve the status quo ante between the parties [...] [section 12(3)] is a much higher test than that there should simply be a prima facie case to get the matter into court. ${ }^{23}$

Hence, by including section 12(3) in the Act, Parliament declared itself content with the notion that claimants should instead make good any losses suffered in consequence of this choice by seeking damages.

Of course, the Cream Holdings test does envisage departure from the balance of probabilities standard in exceptional circumstances. While the court should be 'exceedingly slow' to move from the normal test, it should accept a lower degree of likelihood where the potential adverse consequences of publication may be particularly grave. ${ }^{24}$ Lord Nicholls explained that otherwise the court would be unable to make an order 'in some circumstances where it is plain injunctive relief should be granted as a temporary measure'. ${ }^{25} \mathrm{He}$ expected that any other approach would make for some 'extraordinary' outcomes. ${ }^{26}$ It is far from clear, however, that anticipated privacy harms alone can be sufficient to invoke this exceptional approach. Lord Nicholls proffered a short list of exceptional circumstances: where publication might expose a claimant to risk of serious personal injury (perhaps through criminal retribution or vigilantism), or where a short-lived 'emergency injunction' is required to enable the court to hear and give proper consideration to an application for interim relief. In other cases involving misuse of private information, counsel have argued on at least two occasions that privacy harms should also fall within the exceptional category. ${ }^{27}$ In no case has this argument been successful. ${ }^{28}$

\section{Absence of interim order-making power in the data protection act}

The Data Protection Act 1998 covers the obtaining, processing, and disclosure of personal data relating to data subjects by data controllers. In the immediate context, it covers the acquisition of private information, its storage, consideration, preparation, and publication by media organisations. When the legislation was first introduced, it was thought to promise 'a significant new weapon for individuals to

\footnotetext{
23315 HCDeb 536-537 2 July 1998.

${ }^{24}$ Cream Holdings Ltd v Banerjee, n 20 above, para 22.

25 ibid, para 16

26 ibid, para 19

27 See John v Associated Newspapers Ltd [2006] EWHC 1611 (QB), paras 6-7; A v B, C, D [2005] EWHC 1651 (QB), para 13. While it is not clear from the court report, it seems likely that an argument of this type might was also made, and if so then unsuccessfully, in the case of Mahmood v Galloway [2006] EWHC $1286(\mathrm{QB})$

${ }^{28}$ In the - possibly - analogous scenario of the award of final injunctions contra mundum, the courts have once countenanced harm to privacy alone as warranting especial treatment, but only in the most extreme of circumstances - see X (a woman formerly known as Mary Bell) and Y v O'Brien and others [2003] EWHC 1101 (QB). They have also refused to make such awards in circumstances where only 'mere' harm to privacy was in question - see Re W (A Cbild) [2010] EWHC 16 (Fam).
} 
curb the intrusive excesses of the media'. ${ }^{29}$ It was used regularly in support of privacy actions based primarily upon breach of confidence. ${ }^{30}$ Interest in deploying the Act in cases concerning publication, however, may have diminished. ${ }^{31}$ If this is the case, one explanation is certainly that Parliament determined that it should not be possible to obtain an interim injunction under the Act. ${ }^{32}$

Importantly, in section 32 the 1998 Act includes an exemption that applies in the context of data processing only for the 'special purposes' (those of journalism, art, and literature). The exemption breaks down into two parts: the substantive exemption which absolves data controllers from the duty to adhere to most data protection principles if certain criteria are satisfied, and a procedural exemption. The procedural exemption is found in subsections 4 and 5. Section 32(4) provides that where proceedings are brought against a media organisation in respect of personal data that is being processed with a view to publication, and which twenty-four hours before the proceedings in question had not been published by the data controller, the proceedings must be stayed by the court. ${ }^{33}$ The specific aim of this provision is to ensure that interim injunctions cannot be obtained under the Act in order to prevent media publication. In designing the section 32 procedural bar to pre-publication action, Parliament specifically determined that only damages should be available to remedy harms caused. Manifestly, the legislature does not subscribe to the consensus identified by Professor Phillipson.

\footnotetext{
${ }^{29}$ M. Jelf, Not With a Bang But a Whimper? A Right to Privacy and the End of Voluntary Self Regulation of the Press' (1999) 10(8) Entertainment Law Revien 244, 244.

30 A. Hudson, 'Privacy: A Right by Any Other Name' (2003) Supp (Special issue: privacy) European Human Rights Law Review 73, 79. The seminal case in which the obligations falling upon media companies under the Act were first interpreted was Campbell v Mirror Group Newspapers [2002] EWHC 499 (QB). Passing reference to the Act was earlier made by Lord Justice Brooke in Douglas v Hello! Ltd [2000] EWCA Civ 353 , para 56.

31 H. Fenwick and G. Phillipson, Media Freedom Under the Human Rights Act (Oxford: Oxford University Press, 2006) 721; A. McLean and C. Mackey, 'Is There a Law of Privacy in the UK? A Consideration of Recent Legal Developments' (2007) 29(9) European Intellectual Property Review 389, 394. It is certainly possible to identify actions in which the Act might have been deployed but in fact was not - see, for example, Green Corns Ltd v CLA Verley Group Ltd. [2005] EWHC 958 (QB) (as noted explicitly by $\mathrm{Mr}$ Justice Tugendhat at para 62).

32 Other explanations include the fact that the Act was accorded only cursory treatment by the House of Lords in Campbell ([2004] UKHL 22, paras 32 and 130), and the damages awarded under the head of misuse of private information were not then duplicated under the statute. Moreover, in Douglas $\mathrm{v}$ Hello! Ltd. [2003] EWHC $786(\mathrm{Ch})$, para 239, the claimants recovered only nominal damages on the basis of the Act (beyond the remedy awarded in respect of the main claim).

33 The case can then proceed only in two circumstances: first, if the Information Commissioner determines under section 45 that the exemption does not apply in the circumstances of the case (a process that will involve a substantial delay) (s 32(5)(a)), or secondly, when - in a case where the proceedings were stayed on the making of a claim by the data controller that the processing related to the special purposes - the claim is withdrawn (s 32(5)(b)). In Campbell, the Court of Appeal tentatively added a third scenario, indicating that the statute left this possibility to be inferred: 'presumably, if publication takes place before the Commissioner has ruled on the claim, the stay ceases to be effective' ([2002] EWCA Civ 1373, para 116).
} 


\section{THE ADEQUACY OF DAMAGES AS A PRIVACY REMEDY}

The main purpose of the previous section was not to argue that it is right or best always to rely on damages to remedy privacy harms caused by publication. Indeed, it is conceivable that had the claim for misuse of private information not developed since the introduction of the Human Rights Act, the Data Protection Act scheme would have been open to challenge as being not Conventioncompliant. Rather, the purpose was to highlight that the question of how best to protect the Article 8 interest is one on which there remains room for debate; that there is no consensus on the inadequacy of damages. In the paragraphs that follow, the substantive view that damages are inadequate to remedy privacy harms caused by publication is addressed more squarely.

The primary justification for the contention that interim relief is the only effective remedy in privacy cases is that 'once lost', privacy and confidentiality are 'gone forever'. This is contrasted with defamation where the perceived harm reputational damage - can purportedly be restored through legal vindication. This immediate argument may be sustainable, but it risks eliding the deeper principle. The truth is that it is not unusual for non-monetary harms to be compensated by damages, and the comparison with the unusual tort of defamation does not provide an argument that demonstrates the inadequacy of the damages remedy in all privacy cases.

In many circumstances, the law is asked to provide compensation by way of general damages for non-monetary losses suffered by claimants. Consider the hypothetical situation where a child throws a stone towards - and hits - another in the hope of demonstrating his 'bravery' to a watching audience. The harm to the injured party is caused as a by-product of the perpetrator's primary purpose. No one would argue that monetary compensation for the loss of an eye can restore sight to the victim of such personal injury. Nevertheless, assuming they were awarded at a sufficiently high level, damages would be generally understood to be fair and just satisfaction, and hence an effective remedy. The claimant would of course prefer that the injury had never taken place. It is not clear why privacy harms should be treated differently to this or other forms of irreversible nonpecuniary loss.

A secondary justification for the inadequacy of damages as a remedy is that having failed to obtain an interim award or having never had the opportunity to seek one - claimants are in practice unable to proceed to obtain compensation at trial. That is, that the damages remedy is in practice illusory. Professor Phillipson founds an argument of this type on the supposition that having suffered the ignominy of the first exposure of their private details and/or conduct, claimants will be loath to proceed to trial with the concomitant secondary exposure that this may entail. He cites Max Mosley and Sir Christopher Meyer - the former Chair of the Press Complaints Commission - in support. ${ }^{34}$ The argument was encapsulated

34 Phillipson, n 1 above, 76. 
in the words of Mr Justice Eady in Mosley v News Group Newspapers Ltd: 'once privacy has been infringed, the damage is done and the embarrassment is only augmented by pursuing a court action. ${ }^{35}$ It is certainly true that any interim hearing on privacy cases that occurs is often the determinative stage of the legal process. Moreover, it must intuitively be true that some proportion of cases can be explained by the desire of claimants to avoid further embarrassment. It is not at all clear, however, quite how sizeable this proportion is; nor is it obvious that this should be a relevant factor to which the Strasbourg court should attend.

If the argument is to rest upon the idea that it will be an unusual claimant who proceeds to trial in the face of further onslaughts on his or her privacy - that 'claimants with the degree of resolve of Mr Max Mosley are likely to be few and far between' 36 - then it faces two problems. First, such claims do reach the final trial stage from time to time; media organisations do often agree to settle privacy claims in advance of trial where presumably they are persuaded that the claimant will otherwise proceed to trial, ${ }^{37}$ and alternative regulatory options that potentially promise their own measure of follow-on media attention are quite heavily used in the privacy context. ${ }^{38}$ These factors suggest that many claimants are not at all cowed by the prospect of further embarrassment. Given that the private matters have already been published, a competing assumption to that cited by Professor Phillipson is that some claimants may feel that they stand to lose little more by seeking compensation. Indeed, it would not be surprising if they were sometimes unwisely - motivated by anger to proceed.

Secondly, there are other reasons why claimants may decide not to proceed that are distinct from the fear of pouring oil on fire. In cases where an interim injunction has been refused, this will generally have been because the judge in the interlocutory hearing was not persuaded that the claimant was more likely than not to be successful at trial. The claimant will have received a strong steer from the judge as to whether there is sufficient weight to his or her contention. It might be expected that some will heed this advice. Perhaps more important is the cost

\footnotetext{
35 [2008] EWHC 1777 (QB), para 230.

36 ibid.

${ }^{37}$ Figures on the number of libel and privacy cases resolved in 2008 involving nine national newspaper groups, broadcasters, and news agencies as well as local newspaper publishers were included as an appendix to the preliminary report published by Lord Justice Jackson in May 2009. This demonstrated that there were 15 pure privacy claims resolved in that year (two other resolved privacy complaints also included libel elements), including one at trial (Mosley). The average agreed damages across 14 of these cases was $f^{29} .3 \mathrm{k}$. In the 15 th case, the amount of damages was not clearly stated, although it was probably in the $f, 5-10 \mathrm{k}$ range. The highest agreed damages were $600 \mathrm{k}$ (the same level as the courtawarded amount in Mosley), while no damages were paid in four cases. It is presumed, of course, that 2008 was a representative year. See Jackson, Civil Litigation Costs Review: Preliminary Report. (London: Stationery Office, 2009) app 17.

38 For example, in the year from April 2008-March 2009 (PCC reports 77 and 78), there were ten adjudicated complaints and 55 resolved complaints based upon Clause 3 of the PCC Editor's Code (the generic clause focused on privacy) considered by the Press Complaints Commission. Other regulatory alternatives to legal action include complaint under the Ofcom Broadcast Code and the BBC Editorial Guidelines.
} 
factor, especially when weighed against prospective benefits. Applications for interim relief are typically short in the preparation, and hence are not especially costly. The same cannot be said of proceeding towards a full trial. ${ }^{39}$ Especially where the legal risk is high, many claimants will decide that they are unwilling to bear this financial detriment. This is especially the case in privacy cases where the level of damages awarded in decided cases has tended to be lower than awards in libel actions so that even a successful claimant is likely to face a costs shortfall after damages. This problem may be mitigated where the claim is covered by a conditional fee agreement. ${ }^{40}$

Notably, the argument presented by Professor Phillipson did not cite prohibitive costs as a reason why access to effective justice was not thought to be available to privacy claimants. This is not surprising: the idea that the cost of privacy actions tends to the prohibitive would not be an argument for the disposal of claims at an interim stage when evidence will usually have been pleaded by way of written affidavit only and not cross-examined. It could be an argument for the introduction of some expedited regime for the determining of cases of this type, but that is a separate question to that of whether prior notification should be obligatory.

Even allowing that fear of further embarrassment dissuades some claimants from proceeding to a final trial, this does not mean that for the general case the United Kingdom does not offer an effective remedy. It does not mean that claimants should necessarily have the opportunity to obtain an interim injunction, and hence cannot dictate that prior notification should be obligatory. An interim injunction is not - in law - a final remedy. Indeed, it is questionable whether it should be understood as a 'remedy' at all, given that it does not follow from a full determination of the legal rights and interests at stake in given proceedings. It is an order sometimes made to maintain the status quo in advance of the determination by the court of the substantive legal position. ${ }^{41}$ That the award of an interim injunction will often serve, de facto, as a final remedy is due to the practical reality that such orders are regularly left unchallenged by the defendant or other affected parties.

In this context, it is a curious argument that says that because a claimant chooses not to avail of the opportunity to vindicate his or her Article 8 rights (that

\footnotetext{
${ }^{39}$ Total costs in the Mosley case were measured at over $£ 836 \mathrm{k}$ split broadly equally between claimant and defendant. This sits against the - uniquely high - damages award of $f_{6} 60 \mathrm{k}$ in that case. The average claimant costs for the 14 settled cases was $£, 10,360$, while average defendants costs were $f, 5,220$. The latter figure is likely to be understated as seven of the reported cases cited zero defendant costs. This implies that this subset of the stated figures do not include the cost of in-house legal advice. Accounting for this supposed oversight, defendants costs roughly equate to those for claimants - see, generally, Jackson, n 37 above, app 17.

${ }^{40}$ Interestingly, none of the 15 cases cited in the appendix to the Jackson report (ibid) were covered by a CFA.

41 This fact was reiterated by Lord Hoffmann in Attorney-General v Punch [2002] UKHL 50 (para 74): He noted that conclusions on interlocutory injunctions are reached 'ordinarily to preserve the existing position pending a decision on the merits [...] it does not involve any decision as to whether any particular act falling within the prohibition would, or even arguably would, infringe the plaintiff's rights'.
} 
is, to seek compensation for the putative breach of the right to respect for privacy), the State has somehow failed adequately to protect them. It is akin to arguing, in circumstances where a media defendant elects not to challenge an interim order on grounds of cost, that the State has failed to secure that organisation's Article 10 rights. It is difficult to identify the difference of principle between diffidence based upon fear of further embarrassment and that based upon a dearth of means. In both cases, a putative right has been curtailed. The fact is that while the notion that only an interim injunction will suffice to protect privacy interests is intuitively attractive, on deeper examination - outside extreme and definite versions of the argument - the proposition is not especially persuasive.

\section{ABSENCE OF DUTY TO PRE-NOTIFY THIRD PARTIES AFFECTED BY INTERIM ORDERS}

The comparison adopted above is not a facile one. Rather, it evokes an analogous problem to that faced by the disgruntled claimant who was not informed of pending publication that can also be drawn from the context of the award of interim injunctions. Interestingly, the courts have recently come to recognise this analogous problem. It involves a situation in which a legal notification requirement might allow a media defendant to avoid the imposition of an inappropriate or at least an over-broad, limitation of their freedom of expression. The responses offered may prove instructive with regard to the proposition regarding the need for prior notification of claimants.

As noted above, section 12(2) of the Human Rights Act introduced a general procedural expectation that applications for interim relief will be held inter partes when any award might affect the exercise of the Convention right to freedom of expression. ${ }^{42}$ When an injunction is sought against the media organisation that is threatening to publish, this ensures that the defendant is normally able to make legal representations to the judge in advance of any order being made even though this may be at very short notice.

Section 12(2) does not extend this benefit to any third parties to the action. By virtue of the 'Spycatcher principle', third parties will include any person including other media organisations - who is served notice of the order made. ${ }^{43}$

\footnotetext{
42 Exceptions arise where the court is satisfied that the applicant has taken all practicable steps to notify the respondent $(\mathrm{s} 12(2)(\mathrm{a}))$, or that there are compelling reasons why the respondent should not be notified (s 12(2)(b)). It can be argued that the statutory provision added nothing to the pre-existing common law rules - see Lester, Pannick, and Herberg, n 17 above, para 2.12.2, n 4.

${ }^{43}$ In normal circumstances, orders made by the court - whether at the interim or final stages - bind only those persons to whom they are addressed. The 'Spycatcher principle', however, effectively extends this reach to any person on whom notice of an interim order is served. As explained by Mr Justice Gray in Jockey Club v Buffham [2002] EWHC 1866 (QB), para 26, 'the claimant in a confidence action enjoys [...] a windfall consisting in protection pending trial against invasion of his right of confidentiality by third parties. But the reason for the existence of that windfall is the need for the Court to be able to enforce, through the machinery of the law of contempt, the object for which the interlocutory injunction was granted and not to protect the confidential information as such.' Hence, the third party is not bound by
} 
Importantly, if the named defendant is some person other than a media organisation, this may mean that no legal argument will be presented to the judge that canvasses matters pertinent to publication before an order is made. Moreover, if an application is made against 'persons unknown' there may be no defendant present at all to counter the arguments proffered by the claimant. ${ }^{44}$ Finally, if the claimant can persuade the judge to include terms imposing confidentiality as to the existence of the order - that is, if the judge awards a 'super-injunction' - no third party media organisation will ever learn of the issue concerned unless notice is served by the claimant. Moreover, the third parties who are notified will be told nothing by the applicant about the grounds for the claim, or any possible defence to it. In order to learn more, the third party would have to bear the cost of challenging the order before a court. Precisely this concatenation of issues confronted Mr Justice Tugendhat in John Terry (originally LNS) v Persons Unknown. ${ }^{45}$

There may well be circumstances in which all of the above processes and features prove appropriate to the award of a given interim order. The point is that the media organisations caught by the injunction will find themselves in that predicament without first having had the opportunity to present legal argument to the court. Yet, their rights to freedom of expression will have been curtailed. While they will have the opportunity to challenge the existence or the breadth of terms of the order after it constrains their actions, such a challenge may often not be forthcoming. This may well be on grounds of cost, rather than acquiescence to the legal ruling.

This problem has been recognised by the courts. In the case of $X$ and $Y \mathrm{v}$ Persons Unknown, Mr Justice Eady agreed with counsel that it is important to acknowledge the interests of third parties to the case who are likely in practice to be effectively constrained - albeit by the law of criminal contempt - should an interim order be made.46 Reflecting on the limited scope of the protective obligation in section 12 of the Human Rights Act, he noted that in principle, an extension of the requirements of notification to third parties would be unobjectionable and entirely consistent with Parliament's intention'. ${ }^{47}$ While such third parties would be entitled to mount a challenge to the terms of the order in so

\footnotetext{
the order itself. Rather, the rules of contempt of court operate to ensure that the third party cannot publish information covered by the injunction.

${ }^{44}$ An important foundation for this practice was the decision of Sir Andrew Morritt VC in Bloomsbury Publisbing Group Ltd \& Anor v News Group Newspapers Ltd \& Ors [2003] EWHC 1205 (Ch). The Vice Chancellor undertook an analysis of both the English law and comparative jurisprudence. He noted that the 'over-riding objective' of the Civil Procedure Rules - as expressed in Rule 1.1 - was to enable the court to deal with cases justly. This justified his subsequent conclusion that 'John Doe' orders were permissible, 'the crucial point [...] [being] that the description used must be sufficiently certain as to identify both those who are included and those who are not' (para 21).

45 [2010] EWHC 119 (QB).

46 [2006] EWHC 2783 (QB), paras 9-20.

$47 \mathrm{ibid}$, para 11 . He accepted that there may be 'theoretical difficulties in defining or identifying how far the category of interested third parties extends [...] sometimes [...] it will be clear that the class of persons whose rights will be affected will be different from, and extend more widely than, those persons whom the applicant intends to serve' (para 12).
} 
far as it affected them, 'prevention would be even better than cure'. 48 The upshot was that as a matter of 'best practice' for the future:

where a litigant intends to serve a prohibitory injunction upon one or more [media publishers], in reliance on the Spycatcher principle, those individual publishers should be given a realistic opportunity to be heard on the appropriateness or otherwise of granting the injunction, and upon the scope of its terms. ${ }^{49}$

This suggestion is not backed by any legal obligation. Although conceivable, it is most unlikely that any failure to notify third parties to whom the claimant intends to give notice may be punished in the exercise of the judge's discretion as to whether to make an order. ${ }^{50}$ The parallel to the situation decried by Max Mosley is obvious, and the nature of the putative solution noteworthy.

\section{PRACTICAL CONCERNS WITH A PRIOR NOTIFICATION REQUIREMENT}

Aside from the question of whether the right to respect for privacy may be breached by state reliance upon a remedy in damages only, there may be significant practical obstacles to the operation of a prior notification regime. The generality of this point, along with some particular issues, was recognised by Professor Phillipson. ${ }^{51}$ These obstacles are such, however, as to cast doubt on the feasibility of the proposal, at least to the extent that it involves the imposition of a legal obligation. Some of these difficulties would be specific to the particular notification obligation requested by Max Mosley. ${ }^{52}$ Others would necessarily arise because it would be difficult sensibly to limit the obligation to the claim for misuse of private information. In the former regard, for example, it is not clear on whom the obligation should fall (the mainstream media, the expert blogger, the citizen journalist, the chatroom participant, neighbours gossiping over the privet), or on what categories of information the obligation would bite..$^{53}$ In the latter respect, as

\footnotetext{
48 ibid.

49 ibid, para 18. This idea was elaborated further in paragraph 19 of the judgment by analogy with section 12 of the Human Rights Act 1998.

${ }^{50}$ It would be more likely to see a judge introduce a return date in the order sought. Subsequent cases suggest that this best practice is sometimes honoured in the breach - see, for example, the background to the John Terry case, n 45 above.

51 Phillipson, $\mathrm{n} 1$ above, 94-96.

52 The difficulties that could arise in the context of the actual operation of the proposed legal duty to notify subjects of journalists' stories are canvassed at length in the submission of the Media Lawyers Association to the European court regarding the Mosley application.

53 As Professor Phillipson noted (n 1 above, 94), depending on the manner in which the concept of private information develops over time in domestic law, say to cover any photograph taken in a public
} 
a matter of principle, if the requested prior notification obligation were introduced, it is not easy to see how its extension to other forms of irreversible, non-pecuniary harm could be resisted (confidentiality, some forms of harassment, personal injury, national security, perhaps libel).

The more poignant practical concerns, however, relate to the impact of any general prior notification requirement in privacy cases upon media freedom. That is, the imposition of such an obligation could impinge upon the Article 10 rights of the media organisation involved in any given case, and upon the legal framing of the societal role of the media in general. The extent of this change is uncertain and might easily be overstated, but a notification requirement would be intended specifically to increase the number of instances in which prospective claimants would be able to apply for the award of interim relief. As noted above, in practice injunctions are sometimes awarded at very short notice by non-specialist judges even without the presentation of legal argument by affected media parties. Such injunctions may be unnecessarily broad in their terms, or perhaps even illegitimate in their entirety.

In every additional case in which notice was given under the new obligation, the particular defendant and/or any other media organisation on whom notice of the order is served would have to decide whether to contest or subsequently to challenge the order. Even should they be successful, this would impose an additional cost and a measure of delay into the newsgathering and editorial processes. As Mr Justice Tugendhat has recognised, such costs may easily be disincentive enough to see an investigation spiked. ${ }^{54}$ Often, delay is anathema to news journalism. In Greene v Associated Newspapers Limited, Lord Justice Brooke reflected that 'scoops, as [counsel] observed, are the lifeblood of the newspaper industry $[\ldots]$ he might have added that stale news is no news at all'. ${ }^{55}$ The same idea is familiar in Strasbourg jurisprudence: 'news is a perishable commodity and to delay its publication, even for a short period, may well deprive it of all its value and interest. ${ }^{56}$ It has also previously been noted by Professor Phillipson: 'from the defendant's perspective [...] if the story is topical, even an interim injunction might kill it off completely. ${ }^{57}$ Moreover, the delays involved - even where the media organisation is ultimately successful in having an injunction lifted - can be significant. ${ }^{58}$ This scenario would amount to the procedural licensing by the

place when the subject was not engaged in performance of an official role, the obligation could become extensive indeed. See, generally, K. Hughes, 'Photographs in Public Places and Privacy' (2009) 1 Journal of Media Law 159.

${ }^{54}$ John Terry (originally LNS) v Persons Unknown [2010] EWHC 119 (QB), para 20.

55 [2004] EWCA Civ 1462, para 75.

56 Observer and Guardian v UK (1992) 14 EHRR 153, para 60.

57 G. Phillipson and H. Fenwick, 'Breach of Confidence as a Privacy Remedy in the Human Rights Act Era' (2000) Modern Law Review 660, 691.

58 As noted in the submission of the Media Lawyers Association, in Cream Holdings there was a delay of more than two years between the initial award of the injunction and its lifting by the House of Lords ( $\mathrm{n}$ 20 above); in Napier v Pressdram Limited [2009] EWCA Civ 443, a temporary restraint pending appeal imposed on the refusal to make an award proper for the duration of the appeal process - was in place for five months. In evidence to the House of Commons Select Committee on Culture, Media and Sport, the 
judiciary of the content of media publications. Publishers would have to pay for the right to publish; editorial decisions would be judicially sanctioned. The law reports are replete with warnings as to the inappropriateness of such a predicament. ${ }^{59}$

An unqualified obligation might easily create further problems. They may preclude certain forms of investigatory journalism in which contact could warn subjects of impending exposure and potentially see them abscond or otherwise preempt a desirable outcome. They can allow the subjects time to identify and to pressure whistleblowers into reneging on information provided. ${ }^{60}$ Perhaps more insidiously, a prior notification obligation could promote a bargaining relationship between journalist and subject. It would naturally tend further to encourage 'collaboration' as the opportunity to negotiate over the permissible content of editorial output becomes more prevalent. It is dangerous to overlook the existence of the public relations industry the primary purpose of which is to promote positive images and to deflect deleterious stories. ${ }^{61}$ None of this, while admittedly only an exacerbation of the current predicament of the 'fourth estate', is an edifying prospect.

On these points, and perhaps surprisingly given the readiness with which he accepts the purported practical impact of the non-availability for claimants of an interim order, Professor Phillipson seemed relatively sanguine about the potential chilling effect of a prior notification obligation on journalism. He suggested that delays imposed need not be extended, and as such are not overly significant. Moreover, he argued that assertions of perishability '[amount] only to a rather large generalisation about factual phenomena - that delay will often deprive a story of its value $[\ldots]$ [and that] as such it should generally be treated with caution and not assumed to apply in every case'. ${ }^{62}$ Quite, but it would apply in some cases, and a blanket obligation to notify or even a requirement to notify when serious harm to privacy was likely would still cause some instances of the perceived problem. Professor Phillipson did not mention the costs associated with overturning or

editor of Private Eye explained, We are involved in a case at the moment where we attempted to run a story in January and we still [in May] have not been able to run it. The journalist involved put it to the person involved, which was an error; there was an immediate injunction; we won the case; they have appealed; we are still in the Appeal Court [...] so you find yourself unable to run stories because they have invoked confidentiality or bound it up with privacy and that is a real problem [...] I am sitting on a very good story [...] not about sex, nothing to do with red tops, a proper public interest story [...] and it would have been in the public domain if I had not tried to act responsibly [...] essentially it is censorship by judicial process because it takes so long and it costs so much' - see Select Committee on Culture, Media and Sport, Second Report: Press Standards, Privacy and Libel - Oral and Written Evidence, HC362-II (London: Stationery Office Ltd, 2009-2010) ev190, Q866.

${ }^{59}$ See, for example, Reynolds v Times Newspapers Ltd [2001] 2 AC 127, 200 (per Lord Nicholls); Campbell v Mirror Group Newspapers Ltd [2004] UKHL 22, para 59 (per Lord Hoffmann) and para 112 (per Lord Hope); Re Guardian News \& Media Ltd [2010] UKSC 1, para 63 (per Lord Rodger).

60 Select Committee on Culture, Media and Sport, n 58 above, ev190, Q866, per Ian Hislop.

61 See, generally, N. Jones, 'Max Clifford and Celebrity Journalism: The 'Holier Than Thou' Sage on Media Ethics’ at http:/ /www.nicholasjones.org.uk (accessed April 2010).

62 Phillipson, n 1 above, 90. 
contesting such injunctions as are imposed erroneously or with over-broad effect. He did appreciate that errors would be made at the interim stage, but suggested that the appropriate means of addressing this risk was to improve judicial reasoning at that point. ${ }^{63}$ This is sensible, but impractical in the context of fastpaced decisions based on under-cooked evidence. It also ignores the opportunities for 'game-playing' on the part of claimants.

In some respects, the counterpoints offered here can be understood as expressing sympathy for the devil. The difficulty, of course, is distinguishing the fair organisations, journalists, and stories from foul, when the problem cannot be presumed to rest long in a given location. The appropriate conclusion is that a prior notification obligation would place an illegitimate constraint upon Article 10 in some individual cases, and that it could restrict media freedom in general. This impact should not be overlooked.

\section{ILLEGITIMACY OF STRASBOURG INTERVENTION: THE MARGIN OF APPRECIATION}

In considering the issue of whether the Strasbourg court is free to dictate how states should design the regimes by which they protect Convention rights, as would be necessary if it were to insist that a prior notification obligation must be introduced, Professor Phillipson faced a problem. The court has long recognised that as regards the satisfaction of positive obligations to secure 'respect' for privacy rights, what is required is seldom 'clear-cut' and 'will vary considerably from case to case' in light of the diversity of circumstances and practices followed in different states. ${ }^{64}$ Therefore, the court has accepted that signatories 'enjoy a wide margin of appreciation in determining the steps to be taken'. ${ }^{65}$ This understanding has been affirmed regularly by the European court, and is reflected in recent decisions. ${ }^{66}$ It will apply, as in this context, where the state concerned must determine how best to balance competing Convention rights. Having recognised this difficulty, Professor Phillipson's strategy was to attack its basis. His first tactic was to contend that there is in fact, however implicitly, a consensus regarding the need for a prior notification requirement. His second was to argue that the concept of a margin of appreciation is in any event no longer applicable in this context; to contend that 'such an argument [...] is now out of date'.67

\footnotetext{
63 ibid, 93-94.

${ }^{64}$ Johnston $\mathrm{v}$ Ireland (1987) 9 EHRR 203, para 55.

65 ibid.

66 In Evans v United Kingdom (2008) 46 EHRR 34, para 77, for example, the court noted that 'where [...] there is no consensus within the Member States $[. .$.$] as to the relative importance of the interest at stake$ or as to the best means of protecting it $[\ldots]$ the margin will be wider $[\ldots]$ there will also usually be a wide margin if the State is required to strike a balance between competing [...] Convention rights'.

${ }^{67}$ Phillipson, $\mathrm{n} 1$ above, 79.
} 
The first tactic has not performed its task. In developing his fundamental premise regarding the inadequacy of damages as a privacy remedy, Professor Phillipson undertook a brief comparative glance at the position in some other jurisdictions. He did not profess this to be a comprehensive or detailed analysis, but did use it to support his thesis that there is consensus on the necessity of interim relief (and implicitly therefore on the need for prior notification to make this good). As argued above, what he in fact demonstrated was at best a nearconsensus on the utility of such intervention. Notably, Professor Phillipson's analysis did not identify the existence of prior notification obligations in any other jurisdictions.

A wider review of other jurisdictions would have illustrated that on this specific issue there is a rather more variegated picture. In its submission to the European Court of Human Rights, Guardian News and Media Ltd presented the results of a survey of more than twenty European and international jurisdictions. It highlighted that a prior notification requirement was imposed as a legal duty in a small number of states that were formerly part of or dominated by the Soviet Union, but not in any common law jurisdiction or in other any civil law regime. The intervention concludes that far from there being a near consensus favouring prior notification, there exists 'an international consensus among the great majority of Contracting States against the imposition of [such] a duty'. In its submission, the Media Lawyers Association highlighted European Union legislation and Council of Europe resolutions that affect the media, and pointed out that none of this corpus included a prior notification obligation.

To develop his second tactic, Professor Phillipson cited two recent Strasbourg decisions: Armoniene v Lithuania, ${ }^{68}$ and I v Finland. ${ }^{69} \mathrm{He}$ used the first case to contend that the international court 'is now prepared to stipulate as to the remedy required to protect Article 8 rights against the media'. ${ }^{70}$ On the basis of the second decision, Professor Phillipson argues that 'the absence of effective prospective means of ensuring the security of personal information against unauthorised disclosure may itself amount to a breach of Article 8, despite the availability of ex post facto compensatory damages'. ${ }^{71}$

The problem with these arguments is that neither case does quite what Professor Phillipson requires. While Armoniene is an authority for the argument that the court may intervene with regard to remedies for the protection of Article 8 rights, on the facts it is concerned with a remedy in damages that was capped at such a low level as to be incapable of compensating for the harm caused in the circumstances of the case. It is focused on quantum, and does not dictate that the category of remedy selected was inappropriate. I v Finland does stand as authority

68 (2009) 48 EHRR 53.

69 (2009) 48 EHRR 31.

70 Phillipson, n 1 above, 79 (original emphasis).

71 ibid, 80 (original emphasis). 
for the proposition that Professor Phillipson notes, but importantly, this decision is specific to its facts. It would not be applicable in the context of a prior notification obligation imposed on the media; the right to freedom of expression was not involved in that case, and so it did not concern a balancing of Convention rights. Rather, the case centred on the specific failure of a public body properly to protect privacy rights by securing personal data in accordance with procedures already required under domestic data protection law, and the consequent failure of the state to vindicate the right.

In light of these arguments, it would be a brave international court that intervened in national policy choices to stipulate precisely how mechanisms introduced to balance Convention rights must be designed on the basis of these authorities. The importance of the margin of appreciation concept in this context is that it determines whether it can be legitimate for the court to direct the introduction of the proposed legal obligation. The view that the margin of appreciation should remain wide in this area does not dictate the conclusion that a prior notification requirement (or 'best practice') in privacy cases is undesirable. Rather, it is to assert that any decision to introduce such an expectation must be left to relevant national authorities.

\section{CONCLUSIONS}

This response to Professor Phillipson's paper set out above is intended to serve three purposes. First, to contest the premise that damages cannot be an effective remedy for privacy harm, that interim relief is critical, and that in consequence the United Kingdom is obliged under the European Convention to introduce some form of legal prior notification requirement. Secondly, to assert that the introduction of such an obligation would face significant practical hurdles, and that it would cause interference with the expression rights of media organisations and others in the individual and general case. Finally, in light of the views taken on these prior themes, to argue that it would not be appropriate for the Strasbourg court to compel the introduction of such a mechanism. None of this was to gainsay the fact that, as Professor Phillipson persuasively portrayed, the media does sometimes extinguish the privacy rights of individuals in a wholly unacceptable manner, and that for this reason a prior notification expectation is perhaps desirable. Ultimately, Professor Phillipson's paper is a call for improvements in the system as it stands. The choice over whether and how to introduce such a rule, however, is for national authorities.

If such a reform is deemed necessary or desirable, the immediate question is how this should be done. On this question, Professor Phillipson offered some insightful suggestions including the possibility of allowing the imposition of aggravated or exemplary damages and/or indemnity costs to punish and deter 
non-adherence to the notification obligation. ${ }^{72}$ Since the publication of his paper, the House of Commons Select Committee on Culture, Media and Sport has published the report of its longstanding inquiry into press standards. ${ }^{73}$ This also dealt at some length specifically with Mr Mosley's complaint, and made specific proposals for reform..$^{74}$ The Committee rejected the call for the imposition of a legal obligation, but recommended a damages penalty for breach of a new rule of journalistic ethics to be included in relevant privacy codes. This rule would require prior notification, subject to a public interest override. By virtue of section 12(4) of the Human Rights Act, adherence to the appropriate regulatory rule by the media organisation would then become a justiciable factor in any determination by a judge of the nature of any remedy to be awarded in a privacy case.

One attraction of a combination of the Phillipson and Select Committee proposals is that it would navigate the problem of determining to whom, and in respect of what, the prior notification expectation is to apply. Those covered would be those who commit themselves to the self-regulatory regime overseen by the Press Complaints Commission or those who are bound by their licences to adhere to the Ofcom Broadcast Code as appropriate. Such persons would be covered to the extent that they engage in publication behaviours. Clearly, there is a need to consider the operation of the regime under which interim relief is - or is not - currently made available to those who fear the illegitimate exposure of private information, and the closely-related questions that arise in the context of defamation. The concatenation of problems faced by media defendants, as noted above, also calls for consideration. In this context, it is important and to be welcomed that the Master of the Rolls has recently announced the opening of an inquiry into precisely these topics. The outcomes of that inquiry are anticipated with interest.

\footnotetext{
72 Phillipson, n 1 above, 96.

73 Second Report: Press Standards, Privacy and Libel HC362 (London: the Stationery Office Ltd, 2009-2010).

$74 \mathrm{ibid}$, paras 40-57, 77-93.
} 